\title{
SEQUENCE RECOMBINATION IN EXON 1 OF THE TSPY GENE IN MEN WITH IMPAIRED FERTILITY
}

\author{
Veronika Svacinova ${ }^{a}$, Radek Vodicka ${ }^{a *}$, Radek Vrtel ${ }^{a}$, Marek Godava ${ }^{a}$, Marcela Kvapilova ${ }^{a}$, \\ Eva Krejcirikova ${ }^{\mathrm{a}}$, Ladislav Dusek ${ }^{\mathrm{b}}$, Zbynek Bortlicek ${ }^{\mathrm{b}}$, Jiri Santavy ${ }^{\mathrm{a}}$ \\ ${ }^{a}$ Department of Medical Genetics and Foetal Medicine, Palacky University Olomouc and University Hospital Olomouc, \\ Czech Republic \\ ${ }^{b}$ Institute of Biostatistics and Analyses (IBA), Masaryk University, Brno \\ E-mail:vodickar@fnol.cz
}

Received: December 2, 2010; Accepted with revision: May 5, 2011

Key words: TSPY gene/Male infertility/Y chromosome/SET/NAP domain

Aim. The aim of this study was to evaluate TSPY (testis specific protein on the Y chromosome) gene and 5'UTR (UnTranslated Region) polymorphisms in men with impaired fertility compared to fertile controls.

Methods. We analyzed 72 infertile men and 31 fertile controls usingconventional sequencing analysis to find crucial SNPs (single nucleotide polymorphism) and other changes.

Results. The most remarkable changes were found in the $1^{\text {st }}$ exon only. In one half of the both infertile men and fertile controls, the most frequent finding was 26 SNPs with a similar pattern. In the other half we found highly relevant changes, generating a stop codon in the first third of exon 1. Early termination cut down the protein by $78.5 \%$. This kind of change was not found in the fertile controls. No correlation was found between the spermiogram and the changes leading to the stop codon. The distribution of men with deletions, insertion and higher gene copy number was not statistically different.

Conclusion. The changes found in exon 1 in infertile men could fundamentally affect the process of spermatogenesis. These findings could significantly enhance our understanding of the molecular-genetic causes of male infertility.

\section{INTRODUCTION}

\section{TSPY gene}

The TSPY is a multicopy repetitive gene. Each copy is inserted in a $20 \mathrm{~kb}$ tandem repeat cluster of DYZ5 (ref. ${ }^{1}$ ). The number of copies varies in the population from 35 to 60 , including pseudogenes ${ }^{2}$. The majority of copies are situated on Yp11.2. A few gene units are situated on Yq11.23 (ref. ${ }^{3}$ ). Single copies show high sequence identity ${ }^{4}$. The divergence between functional copies varies from $1 \%$ (ref. $^{5}$ ) to $3 \%$ (ref. $^{6}$ ). The divergence between the functional copies and their pseudogenes together is about $10 \%$ (ref. $^{1,6}$ ).

The human TSPY is a unique member of the TSPY/ SET/NAP1 protein family ${ }^{7-9}$. The members of the SET/ NAP1 protein family encode a protein with a conserved SET/NAP1 domain of approximately 160 amino acids ${ }^{10-12}$. This protein is involved in cell cycle regulation and cell differentiation ${ }^{13,14}$. The TSPY is assumed to be involved in the regulation of entering spermatogonias and primary spermatocytes in male meiosis and in mediating meiotic division ${ }^{15,16}$.

\section{Transcripts and expression}

Each transcription unit is $2.8 \mathrm{~kb}$ long and consists of six exons and five introns (Fig. 1). The most abundant transcript encodes a 308 aa long polypeptide. In the context of ontogenesis, the TSPY has been detected in the $22^{\text {nd }}$ week in foetal testes ${ }^{17}$. The TSPY used to be considered testes specific, expressed in spermatogonia and primary spermatocytes at high levels ${ }^{15}$. Recent studies however, have found TSPY expression in neurons and in pathological tissues: gonadoblastoma in intersex patients, lung cancer ${ }^{9}$, melanoma ${ }^{18}$, testicular germ cell tumours and epithelial cells of prostate cancer ${ }^{11,15,19-21}$.

Two main transcripts (named TSPY-S and TSPY-L) have been described. The difference between them is in the 3' translated region because of alternative splicing. The TSPY-S has a specific C-terminus with 34 amino acids and a total length of 308 amino acids. The TSPY-L has a specific 20 amino acid C-terminus and its total length is 294 amino acids. The two transcripts also differ in ratio of expression; the TSPY-S is approximately three to four times more common ${ }^{22}$.

Sequencing analysis has shown that the TSPY-S corresponds to the TSPY cDNA, described by Zhang et al. ${ }^{17}$ and has a prolonged 3 ' terminus.

\section{TSPY gene functions}

The precise functions of the TSPY gene have not yet been been defined. According to $\mathrm{Lau}^{16}$, and Kido and $\mathrm{Lau}^{21}$, the TSPY serves for the proliferation of embryonic prespermatogonia, embryonic gonocytes, adult spermatogonia and pluripotent stem cells of the male reproductive system. The TSPY protein binds mitotic and meiotic cyclin B. It can affect mitotic and meiotic divisions and accelerate the $\mathrm{G}_{2} / \mathrm{M}$ transition in the cell cycle ${ }^{19,23}$. In addition, rat TSPY can bind histones in the cytoplasm of 


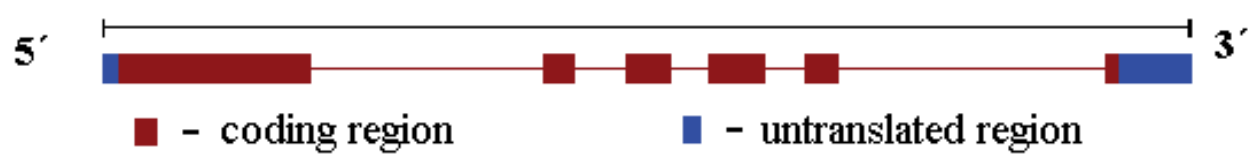

Fig. 1. Modified from NCBI: TSPY1 testis specific protein, Y-linked 1 (Homo sapiens) - human TSPY gene structure.

spermatids. For this reason, it is suggested that the TSPY may function as a chaperone for remodelling of histones that are displaced by protamines in spermatogenesis ${ }^{23-25}$.

\section{MATERIAL AND METHODS}

The men in our study were diagnosed with male infertility between 2002 and 2004 by the WHO criteria ${ }^{26}$, and sent to the Department of Medical Genetics and Foetal Medicine at Olomouc University Hospital to be examined. In total 72 infertile men and 31 controls were investigated. The numbers of patients and controls may, for particular polymorphisms be slightly different from the total number due to failure of sequencing.

The average age of the infertile men was 32.08; the average age of the healthy controls was 33.27. The spermiograms of the infertile men were carefully evaluated and the infertile men were divided into particular groups according to the number of sperms (azoospermia, 0-1, 1-3, 3-5, 5-10, more than 10 million/ml and unknown number of sperms) (Table 1) and also clinically described including a fertility confirmation and paternity analysis in the controls, and a non-consanguinity test between the controls and infertile men by the $\mathrm{Y}$ haplotype analysis (in detail Vodicka et al. ${ }^{27}$ ).

All of the examined individuals had a normal (physiological) karyotype. The project was approved by the Ethics Committee of Olomouc University Hospital. All subjects had been informed about the project and had signed the informed consent.

\section{DNA isolation}

DNA samples were isolated by the salting out method $^{28}$ from $10 \mathrm{ml}$ of peripheral blood. The DNA was preserved in TE buffer. The DNA was diluted to a concentration of $100 \mathrm{ng} / \mu \mathrm{l}$.

\section{PCR}

A simple PCR was used for amplification (Thermal cycler PTC - 200 MJ Research, Waltham MA, USA). Seven TSPY specific loci were chosen and subsequently seven pairs of primers (Table 2).

The PCR conditions: a $20 \mu \mathrm{l}$ of PCR mixture contained $10.0 \mu$ of Combi PPP Master Mix (Top Bio, Prague, Czech Republic), $8.4 \mu$ of PCR water (Top Bio), $0.6 \mu$ of pair of primers $(10 \mu \mathrm{M})$ (Sigma-Aldrich, Seelze, Germany) and $1.0 \mu \mathrm{l}$ of DNA (100 ng/ $\mu \mathrm{l})$. The amplification profile was $94^{\circ} \mathrm{C}$ for $3 \mathrm{~min}, 92^{\circ} \mathrm{C}$ for $1 \min \left(50{ }^{\circ} \mathrm{C}\right.$,
$58{ }^{\circ} \mathrm{C}$ and $61{ }^{\circ} \mathrm{C} / 1 \mathrm{~min}$ ), $72{ }^{\circ} \mathrm{C}$ for $1 \mathrm{~min}$ and the final extension $72{ }^{\circ} \mathrm{C}$ for $7 \mathrm{~min}$. The PCR reaction had 35 cycles.

The PCR products were verified in a $1.5 \%$ agarose gel ( $0.9 \mathrm{~g}$ agarose, $60 \mathrm{ml}$ TBE buffer, $3 \mu$ Ethidium Bromide) by the $100 \mathrm{~V}$ for $30 \mathrm{~min}$. $10 \mu \mathrm{l}$ of the PCR product was loaded into each well. The presence of PCR products was verified with a UV lamp.

The PCR products were purified by the QIAquick PCR Purification Kit, as required by the protocol (Qiagene/ Bio-consult, Prague Czech Republic). After post-PCR purification, the purified DNA was placed in a sequence reaction as a template sequence.

\section{Sequencing PCR}

The first pair of primers was the same pair that we had used for the simple PCR. The second pair was designed for the inner part of the $1^{\text {st }}$ exon. The same primers that were used for the other exons were also used for the simple PCR.

The primers used for sequencing of the $1^{\text {st }}$ exon are listed in (Table 3).

Sequencing PCR conditions: $10 \mu \mathrm{l}$ of the reaction mixture contained $3 \mu \mathrm{l}$ of the sequencing buffer (ABI PRISM - Applied Biosystems, Prague, Czech Republic), $1 \mu \mathrm{l}$ of sequencing kit (ABI PRISM Big Dye, version 3), $2 \mu 1$ of sense (antisense) primer, and $4 \mu \mathrm{l}$ of template DNA. A simple PCR was used for the amplification (Thermal cycler PTC - 200 MJ Research, Waltham MA, USA). The amplification profile was $94^{\circ} \mathrm{C}$ for $2 \mathrm{~min}, 96^{\circ} \mathrm{C}$ for $10 \mathrm{~s}$, and then the temperature started decreasing by approximately $1{ }^{\circ} \mathrm{C}$ per second until it reached $50{ }^{\circ} \mathrm{C}$, then stayed at $50{ }^{\circ} \mathrm{C}$ for $5 \mathrm{~s}$, and finally returned to $60{ }^{\circ} \mathrm{C}$ to remain there for another $4 \mathrm{~min}$. The PCR reaction had 34 cycles.

Post-sequencing purification. $2 \mu \mathrm{l}$ of the working precipitating solution ( $1 \mathrm{ml} 1.5 \mathrm{M}$ of acetate sodium, $1.3 \mathrm{ml}$ of $0.25 \mathrm{M}$ EDTA) were added to $10 \mu \mathrm{l}$ of the sequencing PCR product and centrifuged for $30 \mathrm{~s}$ (24148 rcf). $25 \mu \mathrm{l}$ of absolute ethanol was then added and centrifuged again for $30 \mathrm{~min}$ ( $24148 \mathrm{rcf}$ ). The supernatant was carefully poured out, and $50 \mu \mathrm{l}$ of $80 \%$ ethanol was added. Another centrifugation followed (10 min, $15680 \mathrm{~g}$ ). The supernatant was carefully poured out, and the open tubes were placed in the dryer for $15 \min \left(60^{\circ} \mathrm{C}\right)$. In the next step, Hi Di formamide (Applied Biosystems) was added. After two-minute diffusion and shaking, the content was transferred into clean tubes, denatured at $94{ }^{\circ} \mathrm{C}$ for $2 \mathrm{~min}$ and quickly cooled with ice.

Separation by capillary electrophoresis. Analysis of the TSPY gene was performed with an ABI PRISM 310 Capillary Electrophoresis. Polymer POP4 TM (Applied 
Table 1. Distribution of infertile men according to sperm concentration per ml.

\begin{tabular}{|c|c|c|c|c|c|c|c|}
\hline $\begin{array}{c}\text { Spermio } \\
\text { gram of } \\
\text { infertile } \\
\text { men }\end{array}$ & Azoospermia & $<1 \times 10^{6} \mathrm{ml}$ & $<3 \times 10^{6} \mathrm{ml}$ & $<5 \times 10^{6} \mathrm{ml}$ & $<10 \times 10^{6} \mathrm{ml}$ & $>10 \times 10^{6} \mathrm{ml}$ & $\begin{array}{c}\text { Spermio } \\
\text { gram } \\
\text { unknown }\end{array}$ \\
\hline Number & 20 & 18 & 5 & 5 & 8 & 5 & 11 \\
\hline
\end{tabular}

Table 2. PCR primers and conditions used for amplification TSPY gene.

\begin{tabular}{|c|c|c|c|}
\hline Primer & Sequence & & $\begin{array}{l}\text { Annealing } \\
\text { temperature }\end{array}$ \\
\hline $\begin{array}{l}\text { 1f } \\
1 \mathrm{r}\end{array}$ & $\begin{array}{l}\text { 5' CGGCACAAGTTCCAAG 3' } \\
5^{\prime} \text { TCCCCAAAGAGTCACATC 3' }\end{array}$ & $\begin{array}{l}\text { forward } \\
\text { reverse }\end{array}$ & $58^{\circ} \mathrm{C}$ \\
\hline $\begin{array}{l}3 \mathrm{f} \\
3 \mathrm{r}\end{array}$ & $\begin{array}{l}5 \text { ' GAGGTGCTCTCGGGGAAGTGTAAGTG 3' } \\
5 \text { ' GAGGGTGTATGATTCTGAGGCTGACTG 3' }\end{array}$ & $\begin{array}{l}\text { forward } \\
\text { reverse }\end{array}$ & $61{ }^{\circ} \mathrm{C}$ \\
\hline $\begin{array}{l}5 \mathrm{f} \\
5 \mathrm{r}\end{array}$ & $\begin{array}{l}\text { 5' CATACACCCTCTGTCAACAC 3' } \\
5^{\prime} \text { CTCTTCTTCCACCTGTCAG 3' }\end{array}$ & $\begin{array}{l}\text { forward } \\
\text { reverse }\end{array}$ & $61{ }^{\circ} \mathrm{C}$ \\
\hline $\begin{array}{l}6 f \\
6 r\end{array}$ & $\begin{array}{l}5 \text { ' CGAAGTTGTGGTCAGAGAAC 3' } \\
\text { 5' GACAGGTGGAAGAAGAGAAG 3' }\end{array}$ & $\begin{array}{l}\text { forward } \\
\text { reverse }\end{array}$ & $61{ }^{\circ} \mathrm{C}$ \\
\hline $\begin{array}{l}7 \mathrm{f} \\
7 \mathrm{r}\end{array}$ & $\begin{array}{l}5 \text { ' GTTCTCTGACCACAACTTCG 3' } \\
\text { 5 ' CCTGGATTCTGTCACTCTCTG 3' }\end{array}$ & $\begin{array}{l}\text { forward } \\
\text { reverse }\end{array}$ & $58^{\circ} \mathrm{C}$ \\
\hline $\begin{array}{l}8 \mathrm{f} \\
8 \mathrm{r}\end{array}$ & $\begin{array}{l}\text { 5' CTGGCTGCTCATTTCAG 3' } \\
\text { 5' CAGTCCTTTGTGGTTTGG 3' }\end{array}$ & $\begin{array}{c}\text { forward } \\
\text { reverse }\end{array}$ & $58^{\circ} \mathrm{C}$ \\
\hline $\begin{array}{l}9 f \\
9 r\end{array}$ & 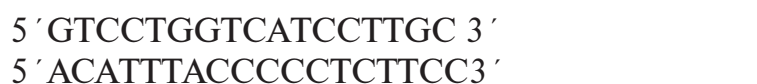 & $\begin{array}{l}\text { forward } \\
\text { reverse }\end{array}$ & $58^{\circ} \mathrm{C}$ \\
\hline
\end{tabular}

Table 3. PCR primers and conditions used for amplification of TSPY gene - exon 1.

\begin{tabular}{|c|c|c|}
\hline Primer & \multicolumn{1}{|c|}{ Sequence } & $\mathrm{T}_{\mathrm{m}}$ \\
\hline 1f & 5' CGGCACAAGTTCCAAG 3' & $50^{\circ} \mathrm{C}$ \\
1r & 5' TCCCCAAAGAGTCACATC 3' $^{\prime}$ & \\
1fi & 5' GATGGAGGCTGTGCAG 3' & \\
1ri & 5' CCACCTCCGCCATTATG 3 & \\
$(\mathrm{i}=$ inner $)$ & & \\
\hline
\end{tabular}

Biosystems) was used as the separating gel. The separation proceeded in a $47 \mathrm{~cm}$ long capillary tube with a diameter of $50 \mu \mathrm{m}$.

Electrophoresis conditions. A sequencing P4StdSeq(1mL)E150s module was adjusted (a sample injection by $1 \mathrm{kV}$ for $30 \mathrm{~s}$ ). The electrophoresis was carried out for $32 \mathrm{~min}$ at $50{ }^{\circ} \mathrm{C}$ and $11.3 \mathrm{kV}$.

The Raw Digital data were collected with the ABI PRISM 310 Data Collection software (by Applied Biosystems) and analysed by the Sequencing analysis software (by Applied Biosystems). The results were compared with a reference genomic DNA sequence $\left(\right.$ ref. ${ }^{29}$ ) using BLAST.

Statistics: The Pearson's Chi-square test and the Fisher's exact test were used for statistical evaluation. Because of the high number of repetitions (the test was repeated 63 times in total) testing corrections of multiple p-values were made, providing more than $5 \%$ false-positive results in all positive results ${ }^{30}$.

The $\alpha=0.05$ significance level was chosen.

Software: R.2.8.1 statistical program.

\section{RESULTS}

Substitutions, deletions and an insertion, their position in the gene, the kind of polymorphism and their frequency in the groups being examined were detected by sequencing analysis. All six exons and a part of 5'UTR were sequenced. Significant changes were observed only in $5^{\text {'UTR }}$ and in the $1^{\text {st }}$ exon. 


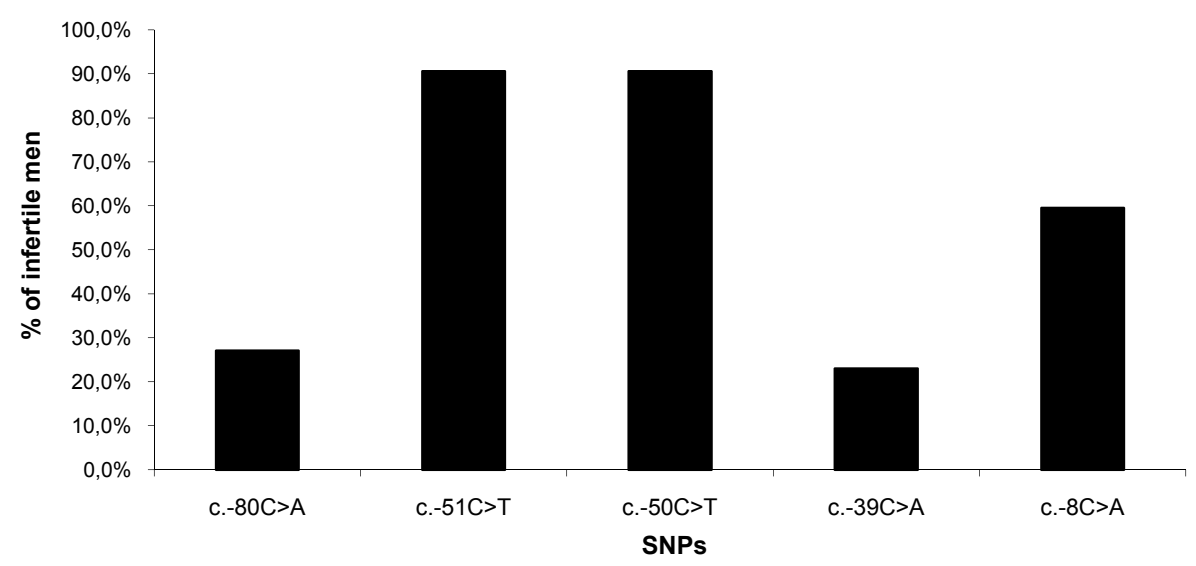

Fig. 2. X axis - the most frequent five SNPs in $5^{\prime}$ UTR TSPY gene in infertile men. SNPs in positions -51 and -50 are the most frequent. Y axis - Percentage occurrance of the most frequent SNPs $(27.7 \%, 93 \%, 93 \%, 23.6 \%$ and $61.1 \%)$.

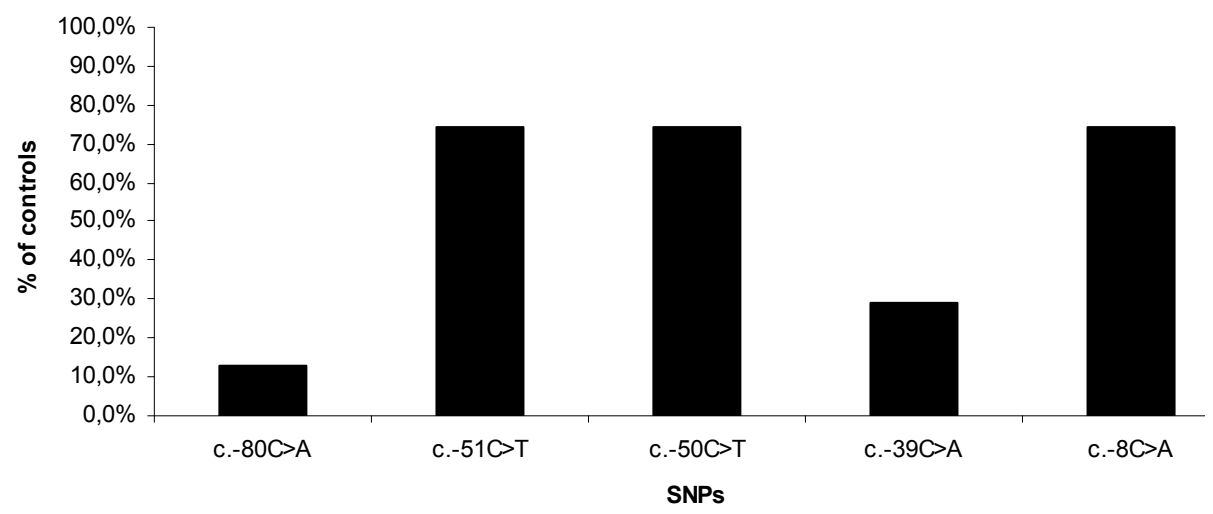

Fig. 3. $\mathrm{X}$ axis - the most frequent SNPs in $5^{\prime}$ UTR TSPY gene in controls. SNPs in positions -51 and -50 are the most frequent. Y axis - Percentage occurrance of the most frequent SNPs $(12.9 \%, 74.2 \%, 74.2 \%, 29.0 \%$ and $74.2 \%)$.

\section{5' Untranslated region}

Two groups were evaluated: infertile men (72) and controls (31).

In this area, the five most frequent SNPs were described. All of them were substitutions. They occurred in positions $-80,-51,-50,-39$ and -8 upstream from the ATG translation initiation codon.

The most frequent SNPs in infertile men were in positions -51 and -50 upstream, and they had the same frequency (Table 4, Fig. 2). Both nucleotides were present or the original nucleotide only (this is analogous to heterozygote but due to the multicopy feature of the TSPY gene it is not a valid comparison) or the base was completely substituted.

The same types of SNPs occurred in controls with a similar frequency. The most frequent polymorphisms were in positions -51 and -50 upstream too (Table 5, Fig. 3). Interestingly, the original nucleotides in the controls were never completely substituted. There was either the original nucleotide only or both nucleotides together.

\section{First exon of TSPY gene}

Polymorphisms were spread all over the exon. Substitutions were the most frequent. All sequence polymorphisms are listed in (Table 7). As the first exon was very long, two pairs of primers were designed. Sometimes the sequencing repeatedly failed in a part of the exon. This is why not the same numbers of infertile men are compared. We compared the number of samples until the c.G177>T position, and the number of samples from the c.G180>A position till the end of the exon (Table 6).

The most important finding was that of a $4 \mathrm{bp}$ deletion and $2 \mathrm{bp}$ substitution at position 36-42. The sequence AGAGAGG was substituted by CAT. This interesting feature was observed in approximately one half of the infertile men. As a result of this deletion and a similar profile of changes (the following substitutions, deletions and one insertion), the infertile men were divided into two subunits.

\section{Infertile men - First subunit}

In the first subunit, the most frequent $26 \mathrm{SNPs}$ were found. All of them were substitutions and $73 \%$ of them caused an amino acid change (Fig. 4, Table 7).

There was one patient in this subunit with a c.G451>A (Val/Ile) substitution which otherwise occurred only in the second subunit of the infertile men. The SNP 
Table 4. Occurrence of SNPs in 5' UTR region TSPY gene - infertile men.

\begin{tabular}{|c|c|c|c|c|}
\hline c. $-80 \mathrm{C}>\mathrm{A}$ & c. $-51 \mathrm{C}>\mathrm{T}^{*}$ & c. $-50 \mathrm{C}>\mathrm{T}^{*}$ & c. $-39 \mathrm{C}>\mathrm{A}$ & c. $-8 \mathrm{C}>\mathrm{A}$ \\
\hline $27,7 \%$ & $93 \%$ & $93 \%$ & $23,6 \%$ & $61,1 \%$ \\
\hline 20 & $43 / 24 \mathrm{~T}^{*}$ & $43 / 24 \mathrm{~T}^{*}$ & 17 & 44 \\
\hline
\end{tabular}

* 43 samples had both nucleotides, 24 had cytosin completly substituted by thymin

Table 5. Occurrence of SNPs in 5' UTR region TSPY gene - controls.

\begin{tabular}{|c|c|c|c|c|}
\hline c. $-80 \mathrm{C}>\mathrm{A}$ & c. $-51 \mathrm{C}>\mathrm{T}$ & c. $-50 \mathrm{C}>\mathrm{T}$ & c. $-39 \mathrm{C}>\mathrm{A}$ & c. $-8 \mathrm{C}>\mathrm{A}$ \\
\hline $12.9 \%$ & $74.2 \%$ & $74.2 \%$ & $29.0 \%$ & $74.2 \%$ \\
\hline 4 & 23 & 23 & 9 & 23 \\
\hline
\end{tabular}

Table 6. Number of examinations regarding to two pairs of primers in $1^{\text {st }}$ exon TSPY.

\begin{tabular}{|c|c|c|c|c|}
\hline & $\begin{array}{c}\text { All infertile } \\
\text { men }\end{array}$ & $\begin{array}{c}\text { Infertile men } \\
(1 . \text { sub })\end{array}$ & $\begin{array}{c}\text { Infertile men } \\
(2 . s u b)\end{array}$ & Controls \\
\hline $\begin{array}{c}\text { Number of samples till } \\
\text { c.G177>T }\end{array}$ & 72 & 41 & 31 & 28 \\
\hline $\begin{array}{c}\text { Number of samples from } \\
\text { c.G180>A }\end{array}$ & 53 & 33 & 20 & 20 \\
\hline
\end{tabular}

c.G214>A (Ala/Thr) was the only one observed solely in the infertile men and not in the control group.

\section{Infertile men - Second subunit}

In the second subunit of the infertile men, different spectra of polymorphisms were observed. Further, these men were different from the ones in the first subunit and from the controls in several other features: in the positions where the other men had both variants of the nucleotide, this group had a mutated allele only. The first two SNPs were present in the majority of the infertile men and controls, but these men only had a mutated allele with no sign of the original nucleotide.

The following polymorphisms, different from the polymorphisms in the first subunit and controls, were observed: 54 substitutions: deletions in positions 36 42, 97, 145, 220, 284 - 286, 290, 294 - 296, 298 - 299 and 305; one insertion of thymine behind position 181 (Fig. 4, Table 7). When all the changes in the $1^{\text {st }}$ exon were summarized, the original length of 486 nucleotides was shorter by 17 nucleotides and with a shifted reading frame consequence. No such changes were observed in the control group.

\section{Control group}

The same 25 most frequent SNPs that were observed in the first subunit of the infertile men (Fig. 4, Table 8) were also found in the control group. The most frequent SNPs were in the c.A80>C, c.G68>A, c.A36>C positions. In this group, no deletions, insertions or substitutions leading to the stop codon were observed.
Spermiogram and changes leading to stop codon

There were no statistically significant differences in the spermiogram outcome between the first and second subunits of the infertile men (Fig. 6). The P-value of the Pearson Chi-square test was 0.755 .

\section{DISCUSSION}

The TSPY gene is a candidate in spermatogenesis regulation ${ }^{31}$. We did a sequence analysis of the gene in order to find polymorphisms or mutations that could be associated with impaired fertility in infertile men.

From the analysis, we were able to examine the most interesting changes in a part of the promoter region and in the first exon of the TSPY gene.

\section{Promoter region}

In the group of infertile men and fertile controls that we had examined, there were 5 common polymorphisms in the 5'UTR region. Polymorphisms in positions -51 and -50 were upstream, ahead of the AP- 2 motives. The infertile men with fully substituted nucleotides in positions -51 and -50 showed the same pattern of changes in the first exon as the second subunit of the infertile men.

Since this phenomenon occurred with a similar frequency in both groups, infertile men as well as fertile controls, these common polymorphisms probably occur in the general male population. 
Controls $(\mathrm{N}=31)$

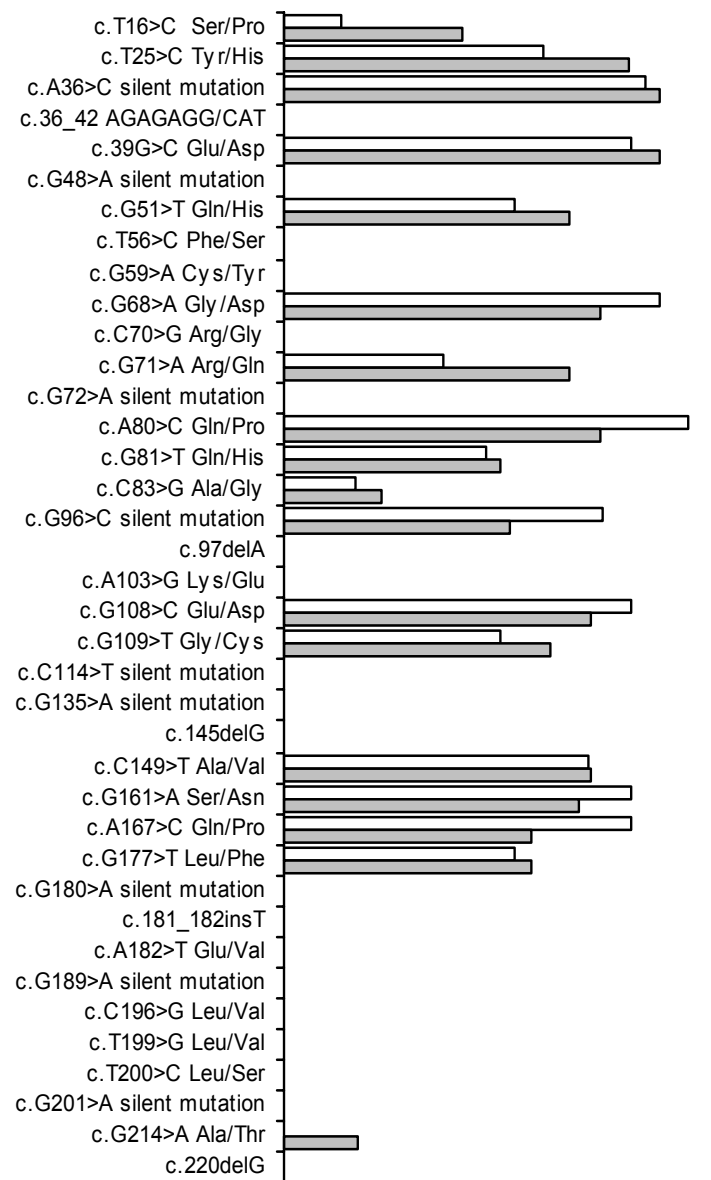

c. G234>C silent mutation c. G235>C Glu/Gln

c.G237>A silent mutation c. G243>A silent mutation c. G246>C Gly/Ala c. C256>G Arg/Gly c. G260>A Arg/GIn c.A263>T Glu/Val c. 277delG c.284_286delAGG c.290delT c. 294_296delTGG c. 298_299delCC c.305delC

c.C312>G silent mutation c.G318>A silent mutation c. G333>C Glu/Asp c. T344>A Val/Asp c. G354>A silent mutation c.A379 $>$ C silent mutation c. G384>C Lys/Asn

c.G417>A silent mutation c.G451>A Val/lle c. G459>A silent mutation c. G478>A Ala/Thr

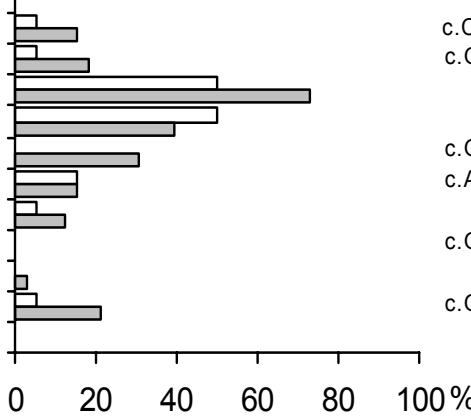

Percentage occurrence
Infertile-2.subunit ( $\mathrm{N}=31)$

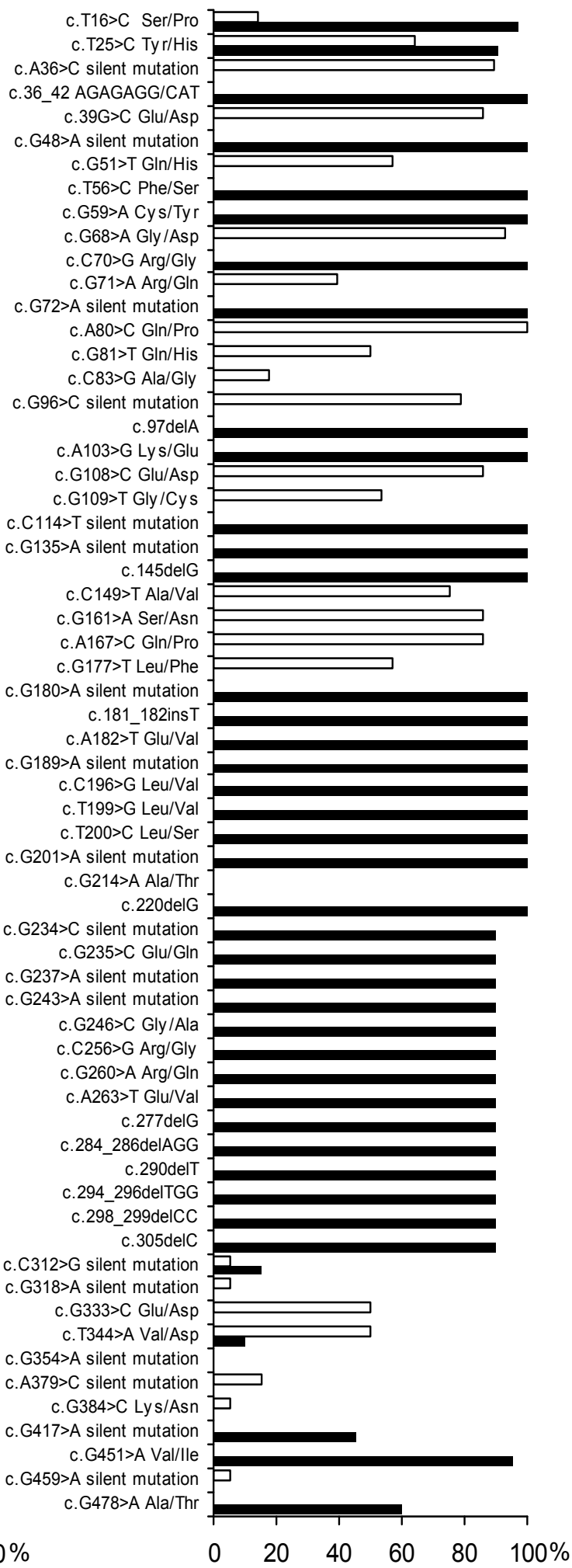

Percentage occurrence

Fig. 4. Comparison of polymorphisms in infertile men and controls. The frequency of all changes in the first exon of TSPY gene in the first subunit of infertile men and controls are shown in the graph on the left side. X axis - Percentage occurrance of the most frequent changes. Y axis - all found changes in infertile men. Graph on the right side demonstrates frequency of all changes in first exon TSPY gene in the second subunit of infertile men and controls. X axis - Percentage occurrance of the most frequent changes. Y axis - all found changes in infertile men: substitutions, deletions and insertion. In this subunit occured mostly other kind of substitutions than in the first subunit of infertile men, all deletions and one insertion. 
Table 7. Frequency of substitutions, deletions and insertions in the $1^{\text {st }}$ exon of TSPY gene in investigated groups.

\begin{tabular}{|c|}
\hline Insertion \\
\hline Substitution in frame shift \\
\hline Substitution \\
\hline Deletion \\
\hline
\end{tabular}

The table describes type of mutation, position in gene and possible change of amino acid. Changes are colour divided according to type of change and its result. "Substitutions"(white) are present in the first subunit of infertile men and controls. "Substitutions in frame shift"(light grey) occurred behind the most important deletion and substitution in position 36-42, which shifted reading frame. "Deletions" (dark grey) occurred only in infertile men and lead to frame shift. "Insertion" (bold in white) was observed only in one position and also causes frame shift.

\begin{tabular}{|c|c|c|c|c|c|c|c|c|}
\hline & \multicolumn{2}{|c|}{ Infertile men } & \multicolumn{2}{|c|}{$\begin{array}{l}\text { Infertile men- } \\
\text { 1. subunit }\end{array}$} & \multicolumn{2}{|c|}{$\begin{array}{l}\text { Infertile men- } \\
\text { 2. subunit }\end{array}$} & \multicolumn{2}{|c|}{ Controls } \\
\hline & $\mathrm{N}$ & $\%$ & $\mathrm{~N}$ & $\%$ & $\mathrm{~N}$ & $\%$ & $\mathrm{~N}$ & $\%$ \\
\hline c.T16>C Ser/Pro & 48 & 66.7 & 18 & 43.9 & 30 & 96.8 & 4 & 14.3 \\
\hline c.T25>C Tyr/His & 63 & 87.5 & 35 & 85.4 & 28 & 90.3 & 18 & 64.3 \\
\hline c. A $36>C$ silent mutation & 38 & 52.8 & 38 & 92.7 & 0 & 0.0 & 25 & 89.3 \\
\hline c.36 42 AGAGAGG/CAT & 31 & 43.1 & 0 & 0.0 & 31 & 100.0 & 0 & 0.0 \\
\hline c.39G $>$ C Glu/Asp & 38 & 52.8 & 38 & 92.7 & 0 & 0.0 & 24 & 85.7 \\
\hline c. G48>A silent mutation & 31 & 43.1 & 0 & 0.0 & 31 & 100.0 & 0 & 0.0 \\
\hline c. G51>T Gln/His & 29 & 40.3 & 29 & 70.7 & 0 & 0.0 & 16 & 57.1 \\
\hline c.T56>C Phe/Ser & 31 & 43.1 & 0 & 0.0 & 31 & 100.0 & 0 & 0.0 \\
\hline c.G59>A Cys/Tyr & 31 & 43.1 & 0 & 0.0 & 31 & 100.0 & 0 & 0.0 \\
\hline c.G68>A Gly/Asp & 32 & 44.4 & 32 & 78 & 0 & 0.0 & 26 & 92.9 \\
\hline c.C70>G Arg/Gly & 31 & 43.1 & 0 & 0.0 & 31 & 100.0 & 0 & 0.0 \\
\hline c.G71>A Arg/Gln & 29 & 40.3 & 29 & 70.7 & 0 & 0.0 & 11 & 39.3 \\
\hline c.G72>A silent mutation & 31 & 43.1 & 0 & 0.0 & 31 & 100.0 & 0 & 0.0 \\
\hline c.A80>C Gln/Pro & 32 & 44.4 & 32 & 78.0 & 0 & 0.0 & 28 & 100.0 \\
\hline c.G81>T Gln/His & 22 & 30.6 & 22 & 53.7 & 0 & 0.0 & 14 & 50.0 \\
\hline c.C83>G Ala/Gly & 10 & 13.9 & 10 & 24.4 & 0 & 0.0 & 5 & 17.9 \\
\hline c.G96>C silent mutation & 23 & 31.9 & 23 & 56.1 & 0 & 0.0 & 22 & 78.6 \\
\hline c.97delA & 31 & 43.1 & 0 & 0.0 & 31 & 100.0 & 0 & 0.0 \\
\hline c.A103>G Lys/Glu & 31 & 43.1 & 0 & 0.0 & 31 & 100.0 & 0 & 0.0 \\
\hline c.G108>C Glu/Asp & 31 & 43.1 & 31 & 75.6 & 0 & 0.0 & 24 & 85.7 \\
\hline c.G109>T Gly/Cys & 27 & 37.5 & 27 & 65.9 & 0 & 0.0 & 15 & 53.6 \\
\hline c.C114>T silent mutation & 31 & 43.1 & 0 & 0.0 & 31 & 100.0 & 0 & 0.0 \\
\hline c.G135>A silent mutation & 31 & 43.1 & 0 & 0.0 & 31 & 100.0 & 0 & 0.0 \\
\hline c.145delG & 31 & 43.1 & 0 & 0.0 & 31 & 100.0 & 0 & 0.0 \\
\hline c.C149>T Ala/Val & 31 & 43.1 & 31 & 75.6 & 0 & 0.0 & 21 & 75.0 \\
\hline c.G161>A Ser/Asn & 30 & 41.7 & 30 & 73.2 & 0 & 0.0 & 24 & 85.7 \\
\hline c.A167>C Gln/Pro & 25 & 34.7 & 25 & 61.0 & 0 & 0.0 & 24 & 85.7 \\
\hline c.G177>T Leu/Phe & 25 & 34.7 & 25 & 61.0 & 0 & 0.0 & 16 & 57.1 \\
\hline c.G180>A silent mutation & 20 & 37.7 & 0 & 0.0 & 20 & 100.0 & 0 & 0.0 \\
\hline c.181 182insT & 20 & 37.7 & 0 & 0.0 & 20 & 100.0 & 0 & 0.0 \\
\hline c.A182>T Glu/Val & 20 & 37.7 & 0 & 0.0 & 20 & 100.0 & 0 & 0.0 \\
\hline c.G189>A silent mutation & 20 & 37.7 & 0 & 0.0 & 20 & 100.0 & 0 & 0.0 \\
\hline c.C196>G Leu/Val & 20 & 37.7 & 0 & 0.0 & 20 & 100.0 & 0 & 0.0 \\
\hline c.T199>G Leu/Val & 20 & 37.7 & 0 & 0.0 & 20 & 100.0 & 0 & 0.0 \\
\hline c.T200>C Leu/Ser & 20 & 37.7 & 0 & 0.0 & 20 & 100.0 & 0 & 0.0 \\
\hline c.G201>A silent mutation & 20 & 37.7 & 0 & 0.0 & 20 & 100.0 & 0 & 0.0 \\
\hline c.G214>A Ala/Thr & 6 & 11.3 & 6 & 18.2 & 0 & 0.0 & 0 & 0.0 \\
\hline c.220delG & 20 & 37.7 & 0 & 0.0 & 20 & 100.0 & 0 & 0.0 \\
\hline c.G234>C silent mutation & 18 & 34 & 0 & 0.0 & 18 & 90.0 & 0 & 0.0 \\
\hline c.G235>C Glu/Gln & 18 & 34 & 0 & 0.0 & 18 & 90.0 & 0 & 0.0 \\
\hline c.G237>A silent mutation & 18 & 34 & 0 & 0.0 & 18 & 90.0 & 0 & 0.0 \\
\hline c.G243>A silent mutation & 18 & 34 & 0 & 0.0 & 18 & 90.0 & 0 & 0.0 \\
\hline c.G246>C Gly/Ala & 18 & 34 & 0 & 0.0 & 18 & 90.0 & 0 & 0.0 \\
\hline c.C256>G Arg/Gly & 18 & 34 & 0 & 0.0 & 18 & 90.0 & 0 & 0.0 \\
\hline c.G260>A Arg/Gln & 18 & 34 & 0 & 0.0 & 18 & 90.0 & 0 & 0.0 \\
\hline c.A263>T Glu/Val & 18 & 34 & 0 & 0.0 & 18 & 90.0 & 0 & 0.0 \\
\hline c. $277 \mathrm{delG}$ & 18 & 34 & 0 & 0.0 & 18 & 90.0 & 0 & 0.0 \\
\hline c. 284 286delAGG & 18 & 34 & 0 & 0.0 & 18 & 90.0 & 0 & 0.0 \\
\hline c.290delT & 18 & 34 & 0 & 0.0 & 18 & 90.0 & 0 & 0.0 \\
\hline c. 294296 delTGG & 18 & 34 & 0 & 0.0 & 18 & 90.0 & 0 & 0.0 \\
\hline c.298 299delCC & 18 & 34 & 0 & 0.0 & 18 & 90.0 & 0 & 0.0 \\
\hline c. $305 \mathrm{delC}$ & 18 & 34 & 0 & 0.0 & 18 & 90.0 & 0 & 0.0 \\
\hline c.C312>G silent mutation & 8 & 15.1 & 5 & 15.2 & 3 & 15.0 & 1 & 5.0 \\
\hline c.G318>A silent mutation & 6 & 11.3 & 6 & 18.2 & 0 & 0.0 & 1 & 5.0 \\
\hline c.G333>C Glu/Asp & 24 & 45.3 & 24 & 72.7 & 0 & 0.0 & 10 & 50.0 \\
\hline c.T344>A Val/Asp & 15 & 28.3 & 13 & 39.4 & 2 & 10.0 & 10 & 50.0 \\
\hline c.G354>A silent mutation & 10 & 18.9 & 10 & 30.3 & 0 & 0.0 & 0 & 0.0 \\
\hline c.A379>C silent mutation & 5 & 9.4 & 5 & 15.2 & 0 & 0.0 & 3 & 15.0 \\
\hline c.G384>C Lys/Asn & 4 & 7.5 & 4 & 12.1 & 0 & 0.0 & 1 & 5.0 \\
\hline c.G417>A silent mutation & 9 & 17 & 0 & 0.0 & 9 & 45.0 & 0 & 0.0 \\
\hline c.G451>A Val/Ile & 20 & 37.7 & 1 & 3.0 & 19 & 95.0 & 0 & 0.0 \\
\hline c.G459>A silent mutation & 7 & 13.2 & 7 & 21.2 & 0 & 0.0 & 1 & 5.0 \\
\hline c.G478>A Ala/Thr & 12 & 22.6 & 0 & 0.0 & 12 & 60.0 & 0 & 0.0 \\
\hline
\end{tabular}




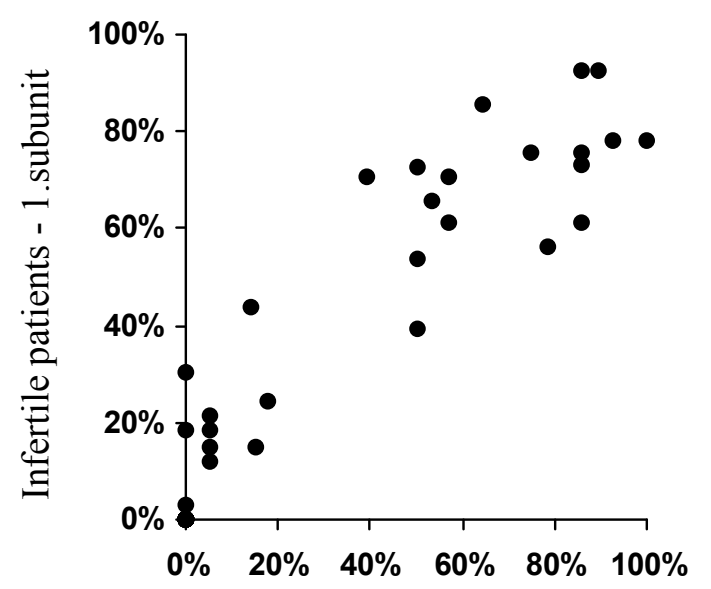

Controls

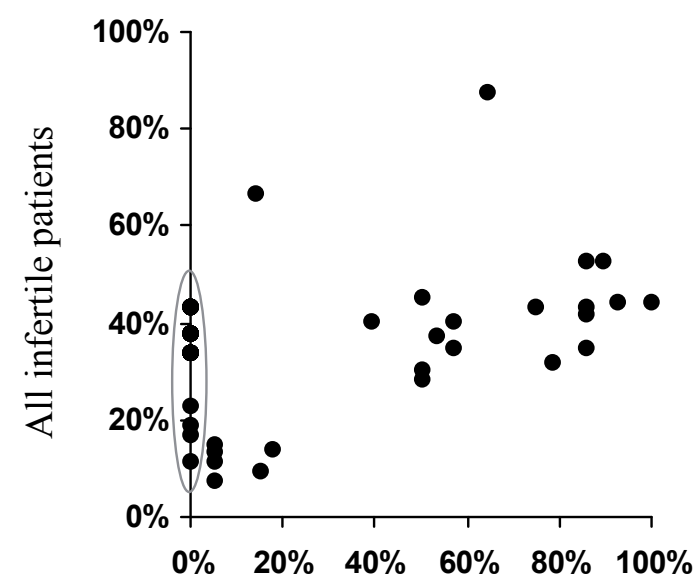

Controls

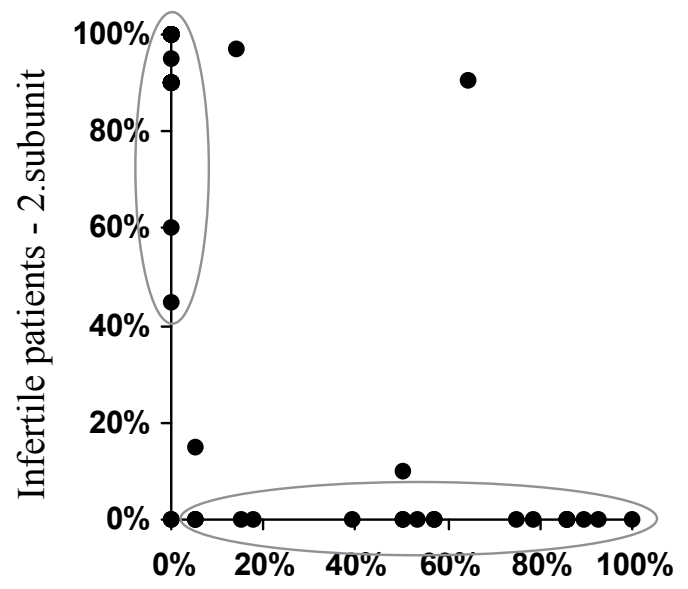

Controls
Each point represents one of the SNPs.

Fig. 5. The percentage incidence of individual changes for all comparisons.

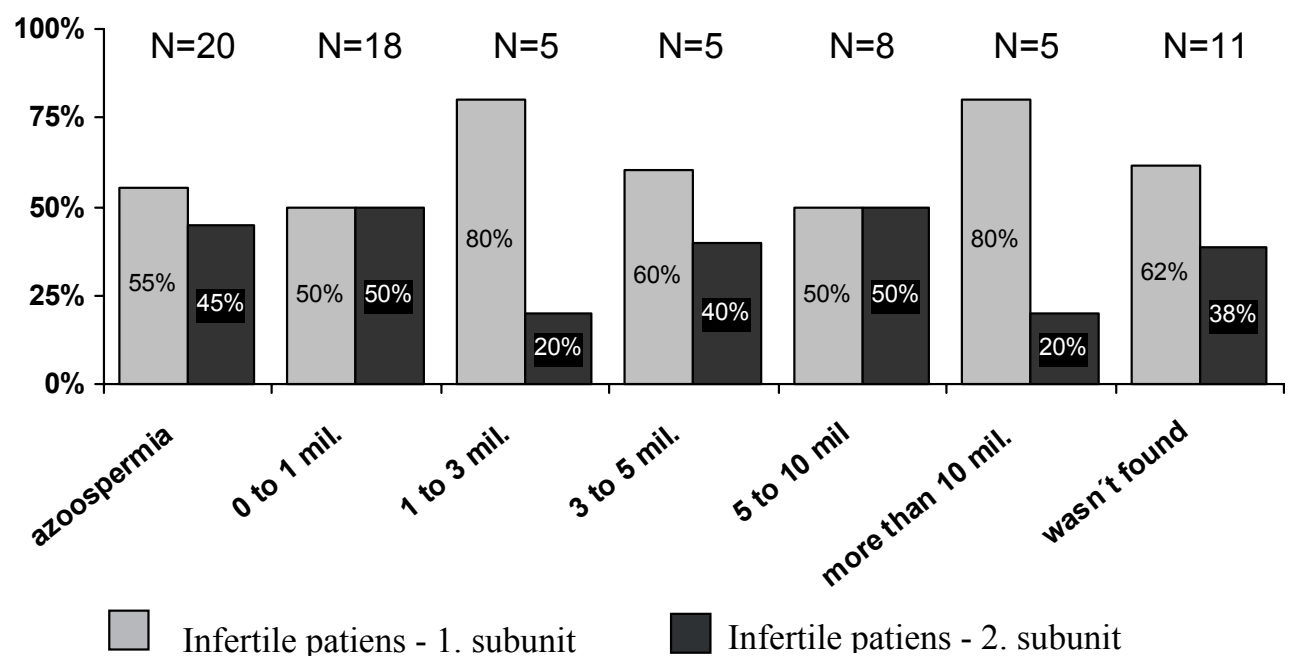

Fig. 6. Comparison of the $1^{\text {st }}$ and $2^{\text {nd }}$ infertile men subunits with spermiogram results. When calculating the Pearson Chi-square test, due to the low category for mating, 1-3 million and 3-5 million, just 5-10 million and more than 10 million were combined. 
Table 8. Summary of Fisher's exact test's results to compare the prevalence of all 63 observed changes between considered groups.

\begin{tabular}{|l|c|c|}
\hline \multirow{2}{*}{ Compared groups } & \multicolumn{2}{|c|}{ Fisher's exact test's results } \\
\cline { 2 - 3 } & $\begin{array}{l}\text { The number of changes with a sta- } \\
\text { tistically significant difference in } \\
\text { the incidence }\end{array}$ & $\begin{array}{l}\text { The number of changes, with no } \\
\text { statistically significant difference } \\
\text { in the incidence }\end{array}$ \\
\hline Controls x Infertile men & $47(74.6 \%)$ & $16(25.4 \%)$ \\
\hline Controls x - 1. subunit of infertile men & $0(0.0 \%)$ & $63(100.0 \%)$ \\
\hline Controls $x$ - 2. subunit of infertile men & $56(88.9 \%)$ & $7(11.1 \%)$ \\
\hline
\end{tabular}

\section{Exon 1 TSPY gene}

Some changes were found in the $1^{\text {st }}$ exon of the TSPY gene leading to various splicing forms and transcripts. Also transcripts which contained hidden donor splicing sites were found in the first exon. The codon for the amino acid 29 was used for splicing three transcripts with three different acceptor splicing sites in either the $1^{\text {st }}$ exon or in the $2^{\text {nd }}$ exon. The transcripts arose between splicing sites 29 and 117, 29 and 134, and 29 and 169 (as early as the $2^{\text {nd }}$ exon) (ref..$\left.^{32}\right)$.

The cryptic RNA splicing variants arose from "inframe" deletions of amino acids 87, 104 and 139. These three variants have been described as a $1 \mathrm{~A}, 1 \mathrm{~B}$ and $1 \mathrm{C}$ exon $^{32}$.

In addition, particular changes, mostly substitutions were identified: the codon 45 (GTG/GTA), the SNP for Valin $^{33}$, the codon 92 (CCC/CGA), Pro/Arg (ref. ${ }^{32}$ ), the codon 93 (CGC/GCA), Arg/Ala (ref. ${ }^{32}$ ), and the codon 195 (CCT/CGT), Pro/Arg (ref. ${ }^{33}$ ).

All of the above polymorphisms were examined and compared with our results.

Substitution in codon 45

The position in c.DNA 135 GTG/GTA $\left(\right.$ ref. $\left.{ }^{33}\right)$.

This SNP occurred in half of the infertile men (31/74).

This SNP did not occur in the control group. At the level of amino acids it is a silent mutation.

Deletion in codon 87

The position in c.DNA 260 CGG/CAG EXON 1A $\left(\right.$ ref. $^{32}$ ).

Only substitution was observed in this position, no deletion. The substitution was found in $24 \%(18 / 74)$ of the infertile men. This change did not occur in the control group. At the amino acid level Arginine was substituted by Glutamine.

Substitution in codon 92

The position in c.DNA 275, $276 \mathrm{CGG} / \mathrm{CCC}\left(\right.$ ref. $^{32}$ ).

This type of SNP was not found in any of our samples.

Substitution in codon 93

The position in c.DNA 277, 278 GCA/CGA (ref. ${ }^{32}$ ).

No substitution, only deletion was observed in position 277 - in $24 \%$ of the infertile men (18/74). The single nucleotide deletion would lead to a shift of the reading frame.

In position 278 no changes in any of the investigated samples were found.

Deletion of codon 104

ACC EXON 2A (ref. ${ }^{32}$ ).

This deletion was not found in any of the samples examined.

Deletion of codon 139

The position in c.DNA 417 CGG/CGA EXON 3A (ref. ${ }^{32}$ ).

In this position only substitution leading to the silent mutation in $12 \%$ of the infertile men $(9 / 74)$ were observed.

Due to the presence of deletions at position 36-42, the group of infertile men was divided into two subunits. The first without deletions at position 36-42 had the same changes as the control group of infertile men. On the other hand, the second subunit of infertile men with deletions at the position 36-42 matched the controls only in seven changes out of all 63 tracked changes.

Exon 1 - First subunit of infertile men

Only substitutions were observed in this subunit. Most of them (74\%) led to a change in the amino acid. With the exception of the SNP c.G214>A (Ala/Thr) all of these substitutions occurred in both groups. Given that the pattern of the SNPs in the first subunit ofinfertile men largely corresponded to the fertile controls, it can be assumed that not all of these SNPs lead to pathological changes or damage to the structure and function of the first exon of the TSPY gene.

\section{Exon 1 - Second subunit in infertile men}

In the second subunit of the infertile men, highly significant changes were observed which fundamentally affected the whole transcript.

As far as the 36-42 deletions and substitutions were concerned, we assume that one adenine was original but we could not decide which one it was. Similarly, we are unable to determine which nucleotides were deleted and substituted. The changes occurring in this subunit cut the original transcript from 486 to 469 nucleotides and shifted the reading frame. 
Stop codon TGA (opal) in this shortened transcript was found in codon 67 and the gene product was cut by $78.5 \%$ and consisted of 66 amino acids.

The TSPY gene is characterized by the presence of a SET/NAP1 specific domain in the $111^{\text {th }}$ to $288^{\text {th }}$ codon $^{12}$. The first exon shares the domain from the $111^{\text {th }}$ to the $162^{\text {nd }}$ codon - about 50 amino acids. For this reason, the domain would be completely missing in the aberrant protein.

The multicopy feature of the gene must be taken into account when assessing the gene product and its function or malfunction. The majority but not allof the gene copies are amplified and then detected by PCR. The PCR is unable to detect and evaluate the changes in sequences of a small number of copies. For this reason, a small copy number of gene polymorphisms remain hidden and not every copy is included in all of these mutations.

We do not know how many copies of the gene are actually expressed. Expression may be influenced by the strength of the promoter or its methylation. The promoter methylation and gene sequences could affect the transcription activity and the secondary structure of the gene product.

When we were evaluating the electrophoretogram, approximately $20 \%$ of the sequences were background which could not be assessed. It is therefore possible that up to $20 \%$ of the copies of the gene are actually missing in the evaluation. The rest of the readable sequences were assessed for SNPs.

In recent years, some studies have found correlations between TSPY gene copy number and male infertility. According to Vodicka et al. ${ }^{27}$, there is also a potential correlation between impaired fertility in males and the TSPY gene copy number. The relative number of copies is higher in infertile men, with the exception of the AZFa deletion case $^{27}$.

Giachini et al. ${ }^{34}$, found that the TSPY gene copy number affects spermatogenesis and that low copy number is a factor contributing to male infertility. On the other hand, Nickkholgh et al. ${ }^{35}$ argue that there is no correlation between impaired spermatogenesis and the TSPY gene copy number.

When evaluating these different results, one should take into account that these studies did not look at the same populations and did not use the same methodologies.
Comparison of TSPY gene copy number and gene polymorphism in particular groups

The proportion of men in the first and second subunit with the gene copy number above or below 0.58 was compared with the Fisher's exact test (Fig. 7).

Figure 7 shows that the number of men with the gene copy number above and below the median is comparable. At $\alpha=0.05$ no statistically significant difference in the proportion of infertile men inthe first and second subunit was revealed (Fig. 8).

In the infertile men group, we compared the copy number and the changes leading to a shift of the reading frame. Approximately half of the infertile men (43.2\%) had a higher relative number of copies than the median 0.58 .

In $40.6 \%$ of the infertile men with a higher copy number, substitutions, deletions and insertion were observed in the first exon, which may lead to a shift of the reading frame or reduction of the first exon transcript length. On the other hand, the remaining $59.4 \%$ of the infertile men with a higher number of copies showed only substitution, also occurring in the fertile controls. No cross-correlation was found in the distribution of infertile men with deletions, insertion, or higher copy number of the gene.

The sample size in the groups according to sperm (Fig. 6) was too small. The results are distorted by small numbers error.

The spermiogram was evaluated only in infertile men. The spermiogram of the control group was not evaluated because of the positive paternity analysis results. Their spermatogenesis was normal.

The comparison of the infertile men's spermiogram and the changes leading to the shift of the reading frame display a rather random distribution. No statistically significant difference was found.

\section{CONCLUSIONS}

In the TSPY gene, various SNPs occurred. The most remarkable changes were in exon 1 . These changes were observed only in a percentage of the infertile men and not in fertile controls. No correlation between the number of copies and significant changes in exon 1 was found.
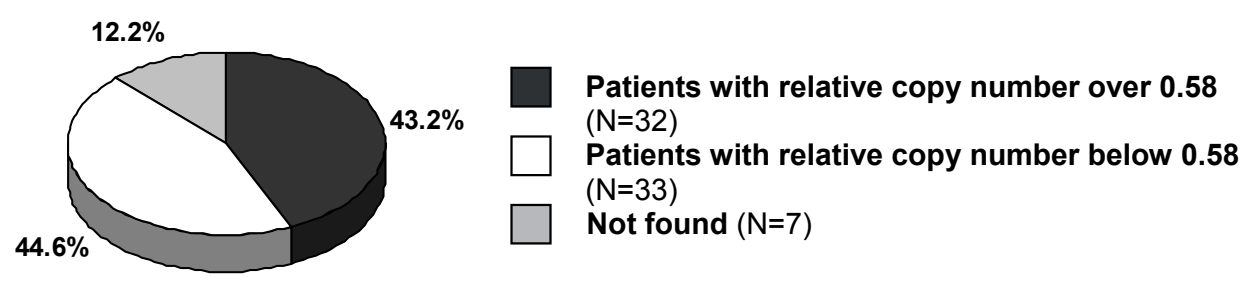

Fig. 7. The ratio of infertile men and the relative number of copies of the gene TSPY. It shows the proportion of infertile men with TSPY gene copy number due to the median of 0.58 . P-value Fisher's exact test is equal to 0.459 . 
Patients with relative copy number over 0.58 $(\mathrm{N}=32)$

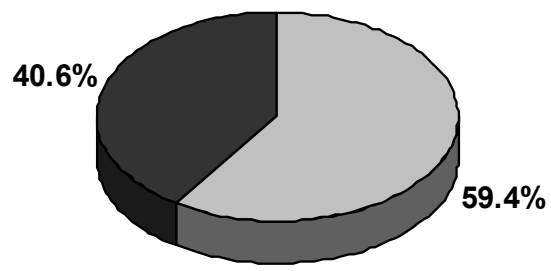

Patients with relativecopy number below 0.58 $(\mathrm{N}=33)$

Infertile men - 1 . subunit

Infertile men - 2. subunit

Fig. 8. Proportion of men given the relative number of copies of the gene TSPY. It shows the proportion of two subunits of infertile men with respect to the relative number of TSPY gene copies.

The changes in the first exon of the TSPY gene may affect the process of spermatogenesis. These data enhance our understanding of the molecular genetic causes of male infertility and gonadal tumorogenesis.

\section{ABBREVATIONS}

AZF, AZoospermia Factor; BLAST, Basic Local Alignment Search Tool; DNA, DeoxyriboNucleic Acid; DYZ5, Amplified DNA fragment on Y chromosome;

MAR, Mixed Agglutination Reaction; PCR, Polymerase Chain Reaction; RNA, RiboNucleic Acid; SET/NAP, Suppressor of variegation, Enhancer of zeste and Trithorax, Nucleosome Assembling Protein; SNP, Single Nucleotide Polymorphism; TE, TRIS, EDTA; TSPY, Testis Specific Protein on Y chromosome; UTR, UnTranslated Region; WHO, World Health Organization

\section{ACKNOWLEDGEMENTS}

Our great thanks go to Dr. Ivana Oborna and Dr. Jiri Dostal of the Olomouc Centre for Assisted Reproduction, who provided us with the samples. Many thanks also to all the patients and family members who participated in this project. This project was supported by the IGA MZ CZ Grant Agency, Grant no. 7821-3/2004-2006.

\section{REFERENCES}

1. Manz E, Schnieders F, Müller Brechlin A, Schmidtke J. TSPYrelated sequences represent a microheterogenous gene family organized as constitutive elements in DYZ5 tandem repeat units on the human Y chromosome. Genomics 1993;17:726-31.

2. Arnemann J, Epplen JT, Cooke HJ, Sauermann U, Engel W, Schmidte J. A. human DNA sequence expressed in testicular tissue. Nucleid Acid Res 1987;15:8713-24.

3. Schempp W, Binkele A, Arnemann J, Gläser B, Ma K, Taylor K, Toder R, Wolfe J, Zeitler S, Chandley AC. Comparative mapping of YRRM- and TSPY-related cosmids in man and hominoid apes. Chromosome Res 1995;3(4):227-34.

4. Skaletsky H, Kuroda-Kawaguchi T, Minx PJ, Cordum HS, Hillier L, Brown LG, Repping S, Pyntikova T, Ali J, Bieri T, Chinwalla A, Delehaunty A, Delehaunty K, Du H, Fewell G, Fulton L, Fulton R, Graves T, Hou SF, Latrielle P, Leonard S, Mardis E, Maupin R, McPherson J, Miner T, Nash W, Nguyen C, Ozersky P, Pepin K, Rock S, Rohlfing T, Scott K, Schultz B, Strong C, Tin-Wollam A, Yang SP, Waterston RH, Wilson RK, Rozen S, Page DC. The male-specific region of the human $\mathrm{Y}$ chromosome is a mosaic of discrete sequence classes. Nature 2003;423(6942):825-37.

5. Skawran B, Schubert S, Dechend F, Vervoorts J, Nayernia K, Lüscher B, Schmidtke J. Characterization of a human TSPY promoter. Mol Cell Biochem. 2005;276(1-2):159-67.

6. Vogel T and Schmidtke J. Structure and function of TSPY, the Y-chromosome gene coding for the "testis-specific protein". Cytogenet Cell Genet 1998;80(1-4):209-13.

7. von Lindern M, van Baal S, Wiegant J, Raap A, Hagemeijer A and Grosveld G. Can, a putative oncogene associated with myeloid leukemogenesis, may be activated by fusion of its 30 half to different genes: characterization of the set gene. Mol Cell Biol 1992;12:3346-55.

8. Vogel T, Dittrich O, Mehraein Y, Dechend F, Schnieders F, Schmidtke J. Murine and human TSPYL genes :novel members of the TSPY-SET-NAP1L1 family. Cytogenet Cell Genet 1998;81:26570.

9. Ozbun LL, You L, Kiang S, Angdisen J, Martinez A, Jakowlew SB. Identification of differentially expressed nucleolar TGF-beta 1 target (DENTT) in human lung cancer cells that is a new member of the TSPY/SET/NAP-1 superfamily. Genomics 2001;73:179-93. 
10. Ishimi Y, Kikuchi A. Identification and molecular cloning of yeast homolog of nucleosome assembly protein I which facilitates nucleosome assembly in vitro. J Biol Chem 1991;266(11):7025-29.

11. Kido T, Lau YF. The human Y- encoded testis-specific protein interacts functionally with eukaryotic translation elongation factor eEF1A, a putative oncoprotein. Int J Cancer 2008;123(7):1573-85.

12. Kido T, Lau YF. The rat Tspy is preferentially expressed in elongated spermatids and interacts with the core histones. Biochem Biophys Res Commun 2006;350(1):56-67.

13. Chai Z, Sarcevic B, Mawson A, Toh BH. SET-related cell division autoantigen-1 (CDA1) arrests cell growth. J Biol Chem 2001;276:33665-74.

14. Canela N, Rodriguez-Vilarrupla A, Estanyol JM, Diaz C, Pujol MJ, Agell N, Bachs O. The SET protein regulates G2/M transition by modulating cyclin B-cyclin-dependent kinase 1 activity. J Biol Chem 2003;278(2):1158-64.

15. Schnieders F, Dörk T, Arnemann J, Vogel T, Werner M and Schmidtke J. Testis-specific protein, Y-encoded (TSPY) expression in testicular tissues. Hum Mol Genet 1996;11:1801-7.

16. Lau YF. Gonadoblastoma, testicular and prostate cancers, and the TSPY gene. Am J Hum Genet 1999;64(4):921-7.

17. Zhang JS, Yang-Feng TL, Müller U, Mohandas TK, de Jong PJ, Lau YF. Molecular isolation and characterization of an expressed gene from the human Y chromosome. Hum Mol Genet 1992;1(9):71726.

18. Gallagher WM, Bergin OE, Rafferty M, Kelly ZD, Nolan IM, Fox EJ, Culhane AC, McArdle L, Fraga MF, Hughes L, Currid CA, O'Mahony F, Byrne A, Murphy AA, Moss C, McDonnell S, Stallings RL, Plumb JA, Esteller M, Brown R, Dervan PA, Easty DJ. Multiple markers for melanoma progression regulated by DNA methylation: insights from transcriptomic studies. Carcinogenesis. 2005;26(11):1856-67.

19. Lau Y, Chou P, Iezzoni J, Alonzo J, Kömüves L. Expression of a candidate gene for the gonadoblastoma locus in gonadoblastoma and testicular seminoma. Cytogenet Cell Genet 2000;91(1-4):160-4.

20. Lau YF, Zhang J. Expression analysis of thirty one Y chromosome genes in human prostate cancer. Mol Carcinog 2000;27(4):308-21.

21. Kido T, YFCh. A Cre gene directed by a human TSPY promoter is specific for germ cells and neurons. Genesis 2005;42(4),263-75.

22. Krick R, Jakubiczka S, Arnemann J. Expression, alternative splicing and haplotype analysis of transcribed testis specific protein (TSPY) genes., Gene 2003;302(1-2):11-19.
23. Lau YF, Li Y, Kido T. Gonadoblastoma locus and the TSPY gene on the human Y chromosome. Review. Birth Defects Res C Embryo Today 2009;87(1):114-22.

24. Mezquita C. Chromatin composition, structure and function in spermatogenesis. Revisiones sobre biologia cellular 1985;5:V-XIV, 1-124. Review.

25. Ivanovska I, Orr-Weaver TL. Histone modifications and the chromatin scaffold for meiotic chromosome architecture. Cell Cycle 2006;(18):2064-71.

26. Available from: http://www.cambridge.org/uk/catalogue/catalogue. asp?isbn $=0521645999$

27. Vodicka R, Vrtel R, Dusek L, Singh AR, Krizova K, Svacinova V, Horinova V, Dostal J, Oborna I, Brezinova J, Sobek A, Santavy J.TSPY gene copy number as a potential new risk factor for male infertility. Reprod Biomed Online 2007;14(5):579-87.

28. Miller SA, Dykes DD and Polesky HF. A simple salting our procedure for extracting DNA from human nucleated cells. Nucleic Acids Res 1988;16:1215.

29. online accessible database of National library of medicine: http:// www.ncbi.nlm.nih.gov/sites/entrez? $\mathrm{Db}=$ gene \&Cmd=ShowDetailV iew\&TermToSearch=7258\&ordinalpos=3\&itool=EntrezSystem 2 . PEntrez.Gene.Gene_ResultsPanel.Gene_RVDocSum

30. Benjamini Y, Hochberg Y. "Controlling the false discovery rate: a practical and powerful approach to multiple testing". Journal of the Royal Statistical Society 1995; Series B(Methodological)57(1):289-300.

31. Oram SW, Liu XX, Lee TL, Chan WY, Lau YF. TSPY potentiates cell proliferation and tumorigenesis by promoting cell cycle progression in HeLa and NIH3T3 cells. BMC Cancer 2006;6:154.

32. Lau YFC, Lau HW and Kömüves LG. Expression pattern of a gonadoblastoma candidate gene suggests a role of the Y chromosome in prostate cancer. Cytogenet Genome Res 2003;101:250-60.

33. Dechend F, Williams G, Skawran B, Schubert S, Krawczak M, Tyler-Smith C, Schmidtke J. TSPY variants in six loci on the human Y chromosome. Cytogenet Cell Genet 2000;91(1-4):67-71.

34. Giachini C, Nuti F, Turner DJ, Laface I, Xue Y, Daguin F, Forti G, Tyler-Smith C, Krausz C. TSPY1 copy number variation influences spermatogenesis and shows differences among Y lineages. J Clin Endocrinol Metab 2009;94(10):4016-22.

35. Nickkholgh B, Noordam MJ, Hovingh SE, van Pelt AM, van der Veen F, Repping S. Y chromosome TSPY copy numbers and semen quality. Fertil Steril 2010;94(5):1744-7. 